\title{
UPAYA PENINGKATAN EFEKTIFITAS PENGAIRAN SAWAH DENGAN SISTEM KONTROL POMPA AIR LISTRIK
}

\author{
Rizal Arifin*1, Muhammad Malyadi' ${ }^{2}$, Edy Kurniawan ${ }^{3}$, Zulkham Umar Rosyidin ${ }^{4}$ \\ 1,2,3,4 Fakultas Teknik, Universitas Muhammadiyah Ponorogo \\ Jl. Budi Utomo No. 10 Ponorogo, 63471 Indonesia \\ *E-mail: rarifin@umpo.ac.id
}

\begin{abstract}
Ngunut is one of the villages in Ponorogo Regency, the majority of whose inhabitants work as farmers. Rice fields in the village of Ngunut are irrigated using ground water extracted with an electric water pump. The process of irrigating rice fields is carried out for several hours, so that the water pump is left on while the farmers are doing other activities. It is often that farmers forget to turn off the water pump, resulting in waste of electricity and the use of ground water. During the dry season, ground water levels can drop below the end of the tow pipe which could potentially cause damage to the water pump. To overcome the problems, we are trying to implement an electric water pump controller that is easy to use by farmers in Ngunut village according to their rice field irrigation needs. By using this control system, potential losses to farmers due to excess electricity costs and damage to water pumps can be prevented. The overuse of ground water can also be avoided.
\end{abstract}

Keywords -Ngunut village, efficiency, rice field irrigation, control system, electric water pump.

\begin{abstract}
Abstrak
Ngunut merupakan salah satu desa di Kabupaten Ponorogo yang mayoritas penduduknya bermata pencaharian sebagai petani. Sawah di desa Ngunut diairi menggunakan air tanah yang diambil dengan pompa air listrik. Proses pengairan sawah dilakukan selama beberapa jam, sehingga pompa air ditinggalkan menyala di saat para petani mengerjakan aktifitas lain. Seringkali terjadi peristiwa dimana petani lupa mematikan pompa airnya, sehingga terjadi pemborosan daya listrik dan penggunaan air tanah. Pada saat musim kering, bisa saja terjadi penurunan tinggi permukaan air tanah sampai di bawah ujung pipa penarik yang berpotensi mengakibatkan rusaknya pompa air. Untuk mengatasi masalah tersebut di atas, kami berupaya menerapkan alat pengontrol pompa air listrik yang mudah digunakan oleh petani di desa Ngunut sesuai dengan kebutuhan pengairan sawah mereka. Dengan penggunaan alat tersebut, potensi kerugian petani akibat biaya listrik berlebih dan kerusakan pompa air dapat dicegah. Pemborosan penggunaan air tanah juga dapat dihindari.
\end{abstract}

Kata kunci-Desa Ngunut, efisiensi, pengairan sawah, alat kontrol, pompa air listrik.

\section{PENDAHULUAN}

Kabupaten Ponorogo terletak di yang terdiri dari 21 Kecamatan dan 307 desa/kelurahan secara astronomis terletak antara 111,7 s.d. 111,52 Bujur Timur dan 07,49 s.d. 08,20 Lintang Selatan dengan luas wilayah sebesar 137.178 Ha. Menurut data dari Badan Pusat Statistik (BPS), luas lahan sawah dan kebun di kabupaten Ponorogo pada tahun 2017 adalah sebesar $73.192 \mathrm{Ha}$ atau sekitar 53,4 \% dari luas wilayah kabupaten Ponorogo (Badan Pusat Statistik Kabupaten Ponorogo, 2018). Desa Ngunut merupakan salah satu desa yang terletak di bagian utara Kabupaten Ponorogo dan dilewati oleh jalur Ponorogo-Magetan. Sebagian besar penduduk desa Ngunut bermata pencaharian sebagai petani. Sebanyak $40 \%$ sawah di desa Ngunut diairi dengan menggunakan air tanah yang diambil menggunakan pompa air, dan sebagian yang lain diairi menggunakan sistem irigasi teknis ("Ngunut, Babadan, Ponorogo," 2019). Pada bulan Mei s.d. 
Oktober, wilayah kabupaten Ponorogo biasanya mengalami musim kering dengan curah hujan yang sangat minim (Badan Pusat Statistik Kabupaten Ponorogo, 2018), sehingga hampir semua petani menggunakan pompa air untuk mengairi sawah mereka pada waktu tersebut (gambar 1).

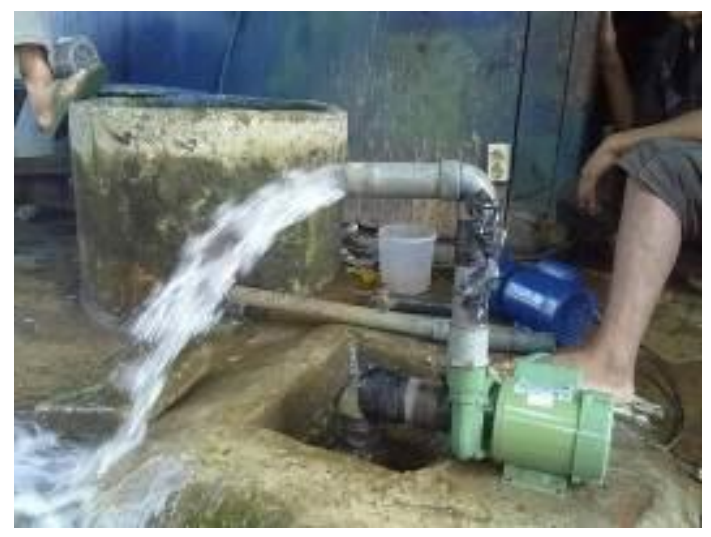

Gambar 1. Pompa Air Listrik untuk Pengairan Sawah (Arifin, Malyadi, \& Kurniawan, 2019)

Penggunaan pompa air listrik dalam pengairan sawah dilaporkan dapat menghemat biaya produksi pertanian sampai dengan 65\% dibandingkan dengan pompa air berbahan bakar solar (Nasrulhaq, 2018). Sebagian besar petani yang ada di desa Ngunut telah menggunakan pompa air listrik untuk proses pengairan sawah. Pompa air listrik mudah untuk dinyalakan cukup dengan menekan saklar, sedangkan jika menggunakan pompa air berbahan bakar disel, para petani yang sudah berumur akan mengalami kesulitan untuk memutar tuas starter (Anam, 2011). Disamping itu, para petani yang mempunyai sawah dengan lokasi yang berjauhan dari rumah, mereka harus menyediakan banyak waktu untuk kembali ke sawah guna melihat ada atau tidaknya masalah dalam proses pengairan yang sedang dilakukan. Bagi sebagian dari petani di desa Ngunut memiliki pekerjaan lain seperti guru, pamong desa, pekerja bangunan, karyawan, dan lain-lain, mereka harus mengeluarkan biaya tambahan untuk mempekerjakan orang dalam proses pengairan sawah mereka. Kadangkala terjadi juga kerusakan pompa air yang disebabkan oleh sumber air yang turun sehingga membuat pompa air menjadi panas dan akhirnya terbakar. Kumparan motor yang ada di dalam pompa air jika tidak ada air yang mengalir melalui saluran pipa jika dibiarkan terlalu lama maka akan membuat motor listrik menjadi panas dan terbakar. Tentunya hal ini sangat merugikan petani karena harga dari pompa air listrik ini juga relative mahal berkisar 3-10 juta tergantung ukuran dan debit air yang bisa dikeluarkan dari sumber air.

Dalam upaya mengatasi masalah di atas, kami memanfaatkan teknologi sistem kontrol pompa air listrik dengan berbagai fitur diantaranya pengatur waktu pengairan otomatis, pengaturan dari jarak jauh melalui layanan pesan singkat (SMS), dan fitur keamanan pemutus daya otomatis ketika tidak ada air yang mengalir melalui pompa. Sistem pengontrol pompa air ini merupakan pengembangan dari sistem yang telah dibuat sebelumnya dengan menggunakan mikrokontroler ATMEGA 16 (Rosyidin, 2017). Sistem kontrol otomatis pada pompa air listrik juga telah banyak dikembangkan dengan konsep penerapan yang beragam, diantaranya sistem pengatur putaran motor listrik pada pompa yang disesuaikan dengan debit air yang mengalir untuk mencegah kerusakan pompa (Rosada, 2017). Penelitian lain yang dilakukan oleh Rahman memperkenalkan sistem elektronik pengontrol pompa air rumahan berdasarkan ketinggian air di dalam tandon (Rahman, 2018). Manembah, dkk. membangun sistem monitor dan proteksi pompa air di Bandar Udara Mutiara Sis Al Jufri (Manembah, IS, \& Wasito, 2017). Pada penelitian yang lain, Saputra dkk., membuat sebuah sistem pengaontrol debit air pada sistem pompa parallel menggunakan Arduino sehingga ketika ada pompa yang rusak atau mati, proses pengambilan air akan dilakukan oleh pompa yang lain (Saputra, Kabib, \& Nugraha, 2019).

Melalui program pengabdian kepada masyarakat ini, kami mempunyai tujuan untuk membantu meningkatkan efisiensi biaya dan waktu yang harus dikeluarkan dalam proses pengairan sawah para petani di desa Ngunut. Target khusus yang ingin dicapai melalui pengabdian kepada 
masyarakat ini adalah mengurangi tingkat pemborosan listrik dan pembuangan air yang sia-sia akibat kelalaian dalam proses pengairan sawah.

\section{METODE}

Dalam Pengabdian ini, kami memberikan solusi atas dua permasalahan mitra yaitu munculnya biaya tambahan karena kurang efektifnya metode pengairan yang selama ini dilakukan dan kurangnya wawasan mitra dalam pemanfaatan teknologi di bidang pertanian.

Langkah-langkah dalam melaksanakan solusi yang ditawarkan adalah:

\section{A. Persiapan}

Tahap ini berupa indentifikasi masalah Tim PKM di Desa Ngunut yakni tentang kondisi sawah dan pompa air yang digunakan untuk mengairi sawah. Mencari tahu masalah dan kendala yang dikeluhkan petani saat proses pengairan sawah.

B. Observasi dan Penggalian Data.

Berdasarkan analisis dan data dilapangan menyatakan bahwasanya mayoritas petani di desa Ngunut menanam Padi dan menggunakan Pompa Air Listrik utuk proses pengairan sawah. Masalah yang muncul adalah sering lupanya petani untuk mematikan pompa air, kondisi sawah yang jauh dari rumah, petani yang mempunyai pekerjaan ganda selain bertani, serta kerusakan pompa air listrik karena sumber air yang turun secara mendadak.

\section{Perancangan Alat}

Perancangan alat kontroler membutuhkan data masukan untuk menciptakan sebuah sistem. Data tersebut didapatkan dari setiap penelitian dan harus dilandasi dengan dasar teori yang ada, guna menciptakan Alat Kontroler Irigasi Sawah yang mampu bekerja dengan benar sesuai harapan petani Alat ini terbentuk dari 2 sistem perancangan yaitu:

\section{Perancangan alat keras}

Perancangan Alat Kontroler Irigasi Sawah secara umum terdiri dari 3 blok, yaitu Input, Control dan Output seperti yang ditunjukkan pada gambar 2.

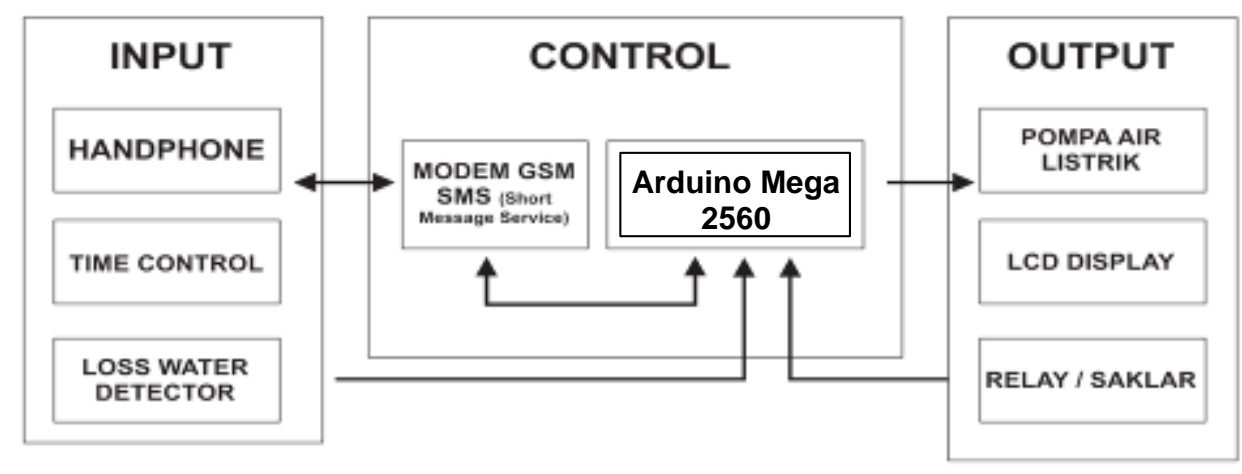

Gamoar $\boldsymbol{L}$. Bagan cara kerja perangkat keras

Secara umum sesuai gambar 2 di atas dapat di jelaskan masing - masing dari 3 Block adalah sebagai berikut:

\section{a. Input}

1) Handphone: difungsikan sebagai pengirim sinyal input berupa SMS yang dikirim ke nomor yang sudah ada dalam Modem GSM dan terprogram di mikrokontroler untuk di proses membangkitkan sinyal output

2) Time control: difungsikan sebagai pengatur berapa lama kita akan menyalakan pompa air untuk proses pengairan sawah.

3) Loss water detector: difungsikan sebagai pendeteksi apabila terjadi penurunan sumber air yang jika diarkan dalam jangka waktu yang lama dapat merusak pompa air 


\section{b. Control}

1) Modem GSM: difungsikan untuk memproses perintah AT Command dari handphone yang kemudian di teruskan ke mikrokontroler untuk di proses.

2) Mikrokontroler Arduino Mega 2560: difungsikan sebagai pengendali utama dari keseluruhan sistem atau bisa disebut sebagai otak dari sistem tersebut.

\section{c. Output}

1) Pompa air listrik: difungsikan sebagai alat untuk mengairi persawahan.

2) LCD display: difungsikan sebagai penampil notifikasi dari system mikrokontroler.

3) Relay/saklar: difungsikan sebagai penyambung dan pemutus arus listrik

\section{Perancangan Perangkat Lunak}

Untuk menjalankan perangkat keras diperlukan perangkat lunak sebagai penggerak sistem, perangkat lunak yang digunakan pada Alat Kendali Irigasi Sawah menggunakan SMS (Short Massage Service) adalah Arduino IDE yaitu sebuah program dari Arduino untuk mengisi Coding sesuai dengan yang kita inginkan. Software ini juga bisa langsung mencompile Coding Program dalam Mikrokontroler Arduino Mega 2560.

Uji coba alat dan penerapan di lapangan

Uji Coba alat perlu dilakukan untuk mengetahui apakah alat sudah bekrja sesuai dengan apa yang kita rancang. Apabila sudah sesuai dengan yang diharapkan maka tahap selanjutnya adalah pemasangan alat di lapangan.

Sosialisai ke mitra dan pendampingan

Alat yang sudah selesai dibuat akan disosialisakan kepada petani mengenai cara penggunaan, cara perawatan, dan cara penanganan apabila terjadi error pada alat. Hal ini penting agar alat yang sudah dibuat dapat secara maksimal bekerja dengan baik sehingga mampu membantu pekerjaan petani. Kegiatan ini merupakan salah satu sarana untuk menambah wawasan mitra tentang penggunaan teknologi di bidang pertanian.

Pemberian alat dan monitoring

Setelah selesai tahap pembuatan, uji coba dan sosialisi langkah selanjutnya adalah pemasangan alat kontroler irigasi sawah kepada para petani. Petani akan merima alat dan akan terus dipantau tim pengabdi untuk system kerja alatnya.

\section{HASIL DAN PEMBAHASAN}

Pada bagian ini, kami menjelaskan proses pengabdian yang dilaksanakan, hasil yang diperoleh, beserta evaluasi yang dilakukan.

\section{A. Forum Diskusi}

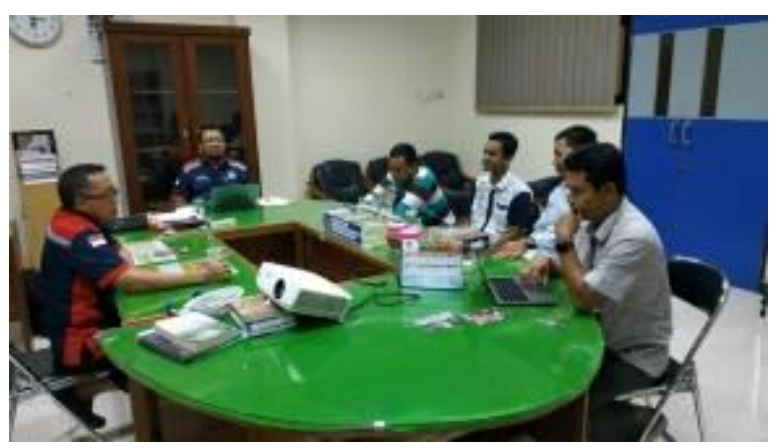

Gambar 3. Koordinasi tim pengabdian kepada masyarakat

Di awal kegiatan, seluruh tim pengabdian melakukan diskusi terfokus untuk membahas langkah kerja dan pembagian tugas setiap orang (gambar 3). Dalam kegiatan ini juga dibahas rancangan 
alat kendali sawah yang akan dibuat, komponen yang harus dipersiapkan, langkah uji coba dan sosialisasi alat kepada para petani di desa Ngunut.

\section{B. Pembuatan Alat Kendali Irigasi Sawah}

Pada tahapan ini komponen yang sudah dibeli dirakit untuk pembuatan Alat. Komponen utama yang digunakan adalah SIM800L sebagai penerima sinyal SMS dari Handphone untuk memberikan masukan sesuai karakter yang sudah diprogram. Input lainnya adalah Keypad untuk memilih durasi waktu yang digunakan petani mangairi sawah. Pemrosesan data dilakukan Mikrokontroler Arduino Mega 2560 nantinya akan memproses sesuai dengan input yang masuk. Alat ini menggunakan RTC (Real Time Clock) sebagai kendali waktu dan memanfaatkan EEPROM yang disediakan Arduino Mega untuk mengatur dan mengunci waktu jika terjadi pemadaman listrik.

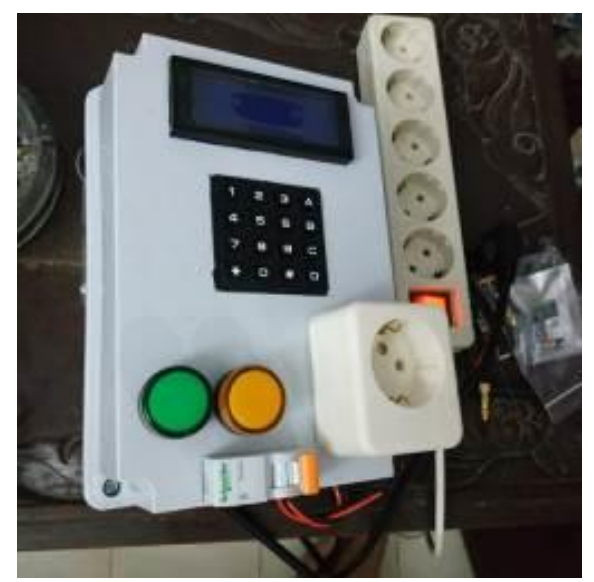

Gambar 4. Alat kontrol pompa air listrik yang telah dibuat

Output dari proses ini akan dikendalikan relay. Relay akan memutus dan menghubungankan tegangan listrik melalui terminal listrik. Sehingga Pompa Air yang terhubung dengan terminal listrik akan hidup dan mati sesuai dengan perintah. LCD akan menampilkan semua aktifitas system sehingga dapat kita pantau input, proses, dan hasilnya secara real time.

Sebagai antisipasi dari kerusakan Pompa Air akibat turunnya debit air atau hilangnya sumber air maka digunakan Sensor Flow Water untuk memonitoring setiap debit air yang mengalir. Jika debit air turun maka sensor akan mendeteksi dan akan memberikan input ke Arduino untuk memutus Tegangan Pompa Air. Pengamanan yang selanjutnya menggunakan TOR (Termal Oveload Relay) yang apabila tidak ada sumber air suhu panas Pompa Air akan meningkat dan Arus juga akan semakin meningkat. Jika terjadi hal demikian maka Relay akan memutus Tegangan Listrik pada terminal dan kemudian alat akan mengirimkan Notifikasi SMS ke Petani.

\section{Pengujian Alat Kendali Irigasi Sawah}

Tahap pertama setting kondisi pompa air dan alat kendali, memastikan semua sudah terpasang dengan benar dan alat dapat menyala dengan baik. Langkah selanjutnya uji alat menggunakan input keypad untuk memilih durasi nyala pompa air.

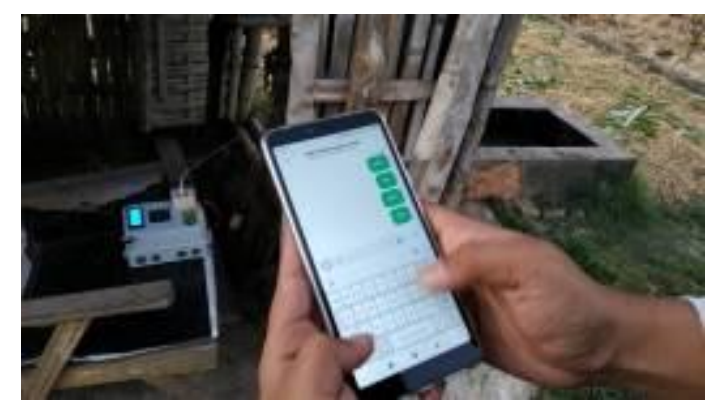

Gambar 5. Pengujian alat dengan menggunakan sms 
Pengujian selanjutnya menggunakan input SMS (Short Message Service) sebagai kendali alat. Alat akan dikendalikan sesuai dengan karakter yang sudah kita program. Apabila karakter yang sudah kita masukkan salah atau tidak sesuai dengan format maka perintah akan diabaikan. Jika benar maka akan menyalakan pompa air dengan durasi yang sesuai dengan karakter.

Jika saat mengairi sawah sumber air turun maka sensor flow water akan mendeteksi dan akan mematikan pompa air. Kemudian akan mengirimkan SMS kepada Petani bahwa alat bermasalah dan Pompa Air dimatikan.

\section{Sosialisasi alat pada kelompok tani di desa Ngunut}

Setelah kami melakukan pengujian alat dan memastikan bahwa semua fitur berfungsi secara optimal, kami melakukan sosialisasi kepada perwakilan kelompok tani di desa Ngunut sebagaimana ditunjukkan pada gambar 6. Kami memberikan materi tentang cara penggunaan alat kontrol yang telah dibuat dengan cara praktek secara langsung di sawah. Pada kegiatan tersebut, masyarakat menunjukkan antusiasme dan ketertarikan yang tinggi tentang fungsional alat yang dibuat. Beberapa petani menyatakan bahwa jika alat tersebut dapat dipasang di pompa air mereka, maka mereka akan lebih punya waktu untuk melakukan aktifitas lain saat pengairan berlangsung, sehingga waktu mereka menjadi lebih efisien. Para petani tidak perlu lagi menunggui proses pengairan sawah sepanjang waktu di sawah.

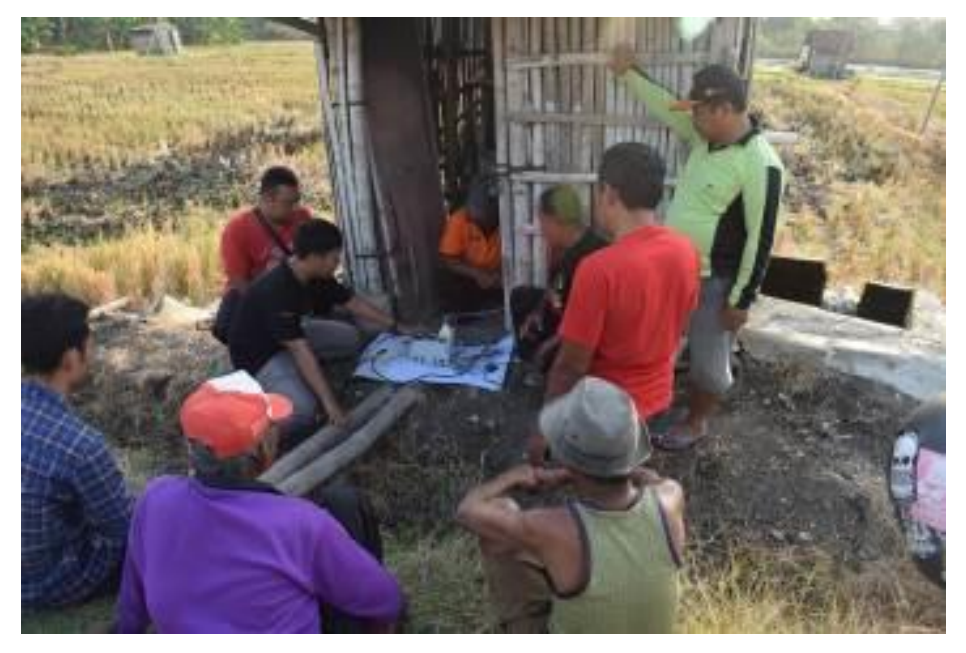

Gambar 6. Sosialisasi cara kerja alat kontrol pompa air listrik di sawah desa Ngunut

\section{KESIMPULAN}

Kami telah berhasil marancang dan membuat alat kontrol pompa air listrik dalam upaya meningkatkan efektifitas pengairan sawah di desa Ngunut, Kecamatan Babadan, Kabupaten Ponorogo, Jawa Timur. Alat kontrol yang dihasilkan mempunyai fitur diantaranya pengatur waktu pengairan otomatis, pengaturan dari jarak jauh melalui layanan pesan singkat (SMS), dan fitur keamanan pemutus daya otomatis ketika tidak ada air yang mengalir melalui pompa. Alat yang dibuat telah berhasil diuji coba dan disosialisasikan kepada petani di desa Ngunut. Kehadiran alat tersebut mendapatkan tanggapan positif dari warga desa sebagai solusi bagi mereka untuk dapat mengatasi permasalahan pada saat pengairan sawah menggunakan pompa air listrik. Petani mempunyai waktu yang lebih banyak yang dapat digunakan untuk melakukan berbagai aktifitas lain baik sosial maupun ekonomi.

\section{SARAN}

Alat kontrol pompa air listrik yang telah kami terapkan untuk membantu meningkatkan efektifitas pengairan sawah di desa Ngunut Ponorogo perlu dikembangkan lebih lanjut. 
Penambahan fitur kontrol dengan sistem aplikasi android mungkin dapat memberikan informasi yang lebih banyak mengenai kondisi pengairan di sawah secara real time.

\section{UCAPAN TERIMA KASIH}

Pengabdian kepada masyarakat ini didanani oleh DRPM-Kemenristekdikti melalui Program Kemitraan Masyarakat dengan Nomor Kontrak 025/SP2H/PPM/L7/2019 dan 86/VI.4/PM/2019.

\section{DAFTAR PUSTAKA}

[1] Anam, S. (2011). Pompa Air Multi Injeksi (PAMI).

[2] Arifin, R., Malyadi, M., \& Kurniawan, E. (2019). Laporan Kemajuan PKM Sistem Pengontrol Jarak Jauh Irigasi Sawah di Desa Ngunut Kec. Babadan Kab. Ponorogo. Ponorogo.

[3] Badan Pusat Statistik Kabupaten Ponorogo. (2018). Kabupaten Ponorogo dalam Angka 2018. Ponorogo: BPS Kabupaten Ponorogo.

[4] Manembah, T. B., IS, R., \& Wasito, B. (2017). Sistem Kontrol Proteksi dan Monitoring Pompa Air Jarak Jauh Menggunakan Wireless Berbasis Mikrokontroler di Bandar Udara Mutiara Sis Al Jufri Palu. In Prosiding Seminar Nasional Inovasi Teknologi Penerbangan (SNITP) Tahun 2017 (pp. 190-193). Surabaya: Politeknik Penerbangan Surabaya.

[5] Nasrulhaq, A. (2018). Petani Bisa Hemat Biaya 65\% Pasok Air Pakai Pompa Listrik. Detik.Com. Retrieved from https://finance.detik.com/berita-ekonomi-bisnis/d-4190027/petanibisa-hemat-biaya-65-pasok-air-pakai-pompa-listrik

[6] Ngunut, Babadan, Ponorogo. (2019). Retrieved September 15, 2019, from https://id.wikipedia.org/wiki/Ngunut,_Babadan,_Ponorogo

[7] Rahman, N. A. (2018). Sistem Kontrol dan Pemantauan Ketinggian Aair pada Tandon dan Daya Pompa Air dengan Android Berbasis Arduino. Universitas Diponegoro.

[8] Rosada, K. (2017). Sistem Kontrol Pompa Air Menggunakan Kontroler PID Berbasis Raspberry Pi. Institut Teknologi Sepuluh Nopember Surabaya.

[9] Rosyidin, Z. U. (2017). Perancangan Alat Kendali Irigasi Sawah Menggunakan Short Message Service (SMS) Berbasis Mikrokontroler ATMEGA 16. Universitas Muhammadiyah Ponorogo.

[10] Saputra, E., Kabib, M., \& Nugraha, B. S. (2019). Rancang Bangun Sistem Kontrol Debit Air pada Pompa Paralel Berbasis Arduino. Crankshaft, 2(1), 73-79. 